\title{
Article
}

\section{A Debt Market Model for the BRICS}

\author{
Mikhail Zharikov
}

check for updates

Citation: Zharikov, Mikhail. 2021. A Debt Market Model for the BRICS. Economies 9: 4. https://doi.org/ 10.3390/economies9010004

Received: 27 November 2020 Accepted: 8 January 2021 Published: 12 January 2021

Publisher's Note: MDPI stays neutral with regard to jurisdictional clai$\mathrm{ms}$ in published maps and institutional affiliations.

Copyright: () 2021 by the author. Licensee MDPI, Basel, Switzerland. This article is an open access article distributed under the terms and conditions of the Creative Commons Attribution (CC BY) license (https:// creativecommons.org/licenses/by/ $4.0 /)$.
World Finance Department, University under the Government of the Russian Federation, 125993 Moscow, Russia; michaelzharikoff@gmail.com or mvzharikov@fa.ru

\begin{abstract}
The author introduces an approach for a consensual economic policy for a group of rapidly developing countries as a response to contemporary global economic challenges. This article reconsiders the problems of international economic integration in the period of deglobalization. The author puts forward the hypothetical model of a debt market of BRICS-bonds. The paper discusses approaches to servicing government debt and budget deficits in the BRICS based on the shared framework of financial and economic institutions. The author formulates the possibilities of a shared economic policy in the BRICS that could help overcome the consequences of the crisis caused by COVID-19. The author proposes a unique budget deficit optimization approach for the BRICS. The article evaluates the options for automatic and state-run budget deficit services and identifies the optimal level of taxation and the average weighted tax rate for the BRICS. The author investigates the potential of the BRICS to use financial resources of the shared debt market based on the gradualist approach for a consensual economic policy.
\end{abstract}

Keywords: consensual economic policy; BRICS-bonds; regional debt market; world coronavirus crisis; world economic order; debt optimization practices; optimal tax rate; approaches to debt servicing in the BRICS; F14; F17

\section{Introduction}

The purpose of this article is to try to work out the principles that can be used to establish a shared mechanism of economic policy for the BRICS. Currently, it is timerelevant to talk about shared economic policy because of the fact that many countries of the world mistakenly seek to decouple from international integration processes and isolate themselves from each other. The ongoing pandemic of 2020 has proven that with no cooperation and negotiation mechanisms, the world is very shaky and powerless when dealing with wide-scale crises. Therefore, this paper argues that, especially nowadays, there is an increasing need for multilateral mechanisms for solving such global problems. The hypothesis is that informal groupings such as the BRICS may become an alternative that can help find solutions to existential threats and challenges. This research is novel since it makes an attempt to lay the foundations for a shared economic policy mechanism in an informal group of countries with multilateral institutions responsible for specific problems such as money circulation, provision of loans, debt relief, etc.

In times of crises, a national currency has often been an instrument to help an economy recover when the government faces a fiasco. A currency can be inflated and devalued, which may sometimes help soften the implications for the national economy. This strategy is part of protectionist policies. However, as Gourinchas and Obstfeld (2012) discovered, a currency cannot be inflated and devalued to infinity. The monetary authority responsible for its issue must also be very cautious and prudent about changes in the money supply.

In extreme circumstances, such as today's, the times of the coronavirus pandemic, as many governments in different parts of the world try to stimulate their economies by means of large-scale quantitative easing and fiscal plans, money supply tends to be changed and adjusted on a repetitive basis, usually out of schedule. Therefore, as Hou and Li (2020) reported, determining the limits of the money supply is a very difficult task, especially 
during global financial and economic crises, during which many governments require excessive amounts of spending and liquidity.

Few countries in the world have the capacity to provide lender-of-last-resort facilities when there is an urgent need for more currency. In this respect, research states the importance of looking for cointegrating countries such as the BRICS (Badshah and Bulut 2020). The last couple of decades of the 21st century saw a few examples when the world had an urgent need for a central-bank-for-the-world function (Cao and Wang 2020). The most notable events include the 2007-2009 world financial crisis and the global downturn caused by the ongoing coronavirus pandemic in 2020. These crises highlighted risks for banks and put them on the brink of collapse (Rahman et al. 2020). Circumstances such as these bring about acute discussions of the world economic order and reforms of the international financial architecture established after the second world war (Fu et al. 2020).

Policymakers usually start talking about reforming the world monetary system and the international financial architecture when there is an immediate threat to the world economic order and when the US is in trouble. Tsai et al. (2019) believe there is a very short timeframe when the largest emerging countries of the world feel to be prosperous and bold enough to challenge the US as the central economic and financial power. This paradoxical prosperity has led many to think that the time has come for the US to step aside and let China and co. restructure the world economic order to their liking. The BRICS prosperity is paradoxical because, despite the fact that it enjoys the world's largest foreign exchange reserves of close to 5 trillion dollars, the population at large lives in poverty in these countries (Dong et al. 2019).

The BRICS began making proposals for the new world financial architecture in the aftermath of the world financial crisis of 2007. In 2010-2012, the BRICS was very quick and eager to announce that it was very possible that it could reform the international financial architecture and create the new world economic order based on the multipolar system of the most capable countries, which would be fairer and more just than the one-polar world with the US and dollar dominance (Sun et al. 2019). However, the majority of these countries preferred the established world economic order under the US economy's leadership and with the US dollar dominating the world financial system (Wang et al. 2019). This situation has been mistakenly considered by many, including Younsi and Bechtini (2020), as the US losing its leadership in the world, delinking, and trying to trigger deglobalization.

The unwillingness of major economies to come together and the lack of cooperative efforts will only prolong the world economic crisis caused by COVID-19. Global powers and institutions being unable to deal with the current situation will make many countries go their own way locally or regionally. Hence, there is a strong need for more local and regional efforts, one of which can be a regional market of debt obligations.

\section{Methodology}

The period of 2020 and thereafter is going to be a time for the governments of the BRICS to introduce various economic stimulus plans to help overall recovery. Many researchers such as Gao et al. (2020) suggest that a lot of countries in the world, including the BRICS, are expected to be running at enormous budget deficits and government debt as a result of the economic and healthcare crisis. To solve this problem, the author proposes that the BRICS should try to establish a shared debt market to deal with government bond instruments.

To achieve the objectives of this research, the author attempted to combine the idea behind the Maastricht criteria, which laid the foundation of financial integration in the euro area and the monetarist principles of stable money supply and inflation targeting. Monetarists always said it was absolutely important to keep the money supply in line with the relevant GDP growth. They said the money supply must cover the economic output 
as 1 to 1 . If a central bank produced more money, it would cause higher inflation. The calculations proceeded via the following Formulas (1)-(3):

$$
\begin{gathered}
Y_{t o}=\frac{M C}{G D P} \times 100 \% \\
S C=I_{t o} \times G D P \times 100 \% \\
G D P=\frac{C S \times 100 \%}{Y_{t o}}
\end{gathered}
$$

To make it clear, $Y_{\text {to }}$ stands for the economic output covered by the supply of credit in an economy and is a constant value, meaning that it should stay the same during the harmonization period. SC signifies credit supply, which could potentially result from the introduction of a shared loan rate for the BRICS, which euro-area countries experienced to a full extent after the introduction of the common rate of refinancing. Countries with weaker economies and higher interest rates joined stronger nations with lower interest rates and started to enjoy the benefits of the single capital market, which provided them with cheaper credit. This situation later led to higher debts in the weaker nations of the euro area and financial difficulties in Greece, for example. To avoid that, in the BRICS, this research suggested that harmonization must proceed very cautiously and gradually while keeping in mind the monetarist idea about price stability. The author tried to calculate the impact of a probable credit supply as a result of fiscal harmonization in the BRICS. To do that, the researcher went on to determine the volume of GDP that could come from the increase in credit if the BRICS agreed on a shared loan rate at a lower level.

An important challenge the BRICS is going to face while introducing shared debt market instruments will be finding how much liquidity should potentially be put into circulation in the money and debt markets. This is crucial since it may help determine the demand for the BRICS' debt instruments. If the new BRICS-bonds had circulated and were sold on the supposed debt market, there might have also been a problem with the depreciation of assets caused by increasing the money supply and liquidity home and abroad.

One more problem about the BRICS-bonds is different income tax rates, VAT rates, corporate tax rates, etc. To solve the differences in the tax systems, the BRICS needs to agree on adequate consensual budgetary and fiscal policies. According to a hypothetical agreement on the consensual budgetary and fiscal policies, the annual average weighted tax rates in the BRICS should not exceed specific bounds within which the budgets could be balanced to ensure economic stability and a sustainable budget deficit and government debt. In terms of the consensual budgetary and fiscal policies of the BRICS, the member states should aim at achieving the following conditions: in year one, say 2020, of functioning consensual fiscal and budgetary policies in the BRICS, the average weighted tax rates must settle at a level that would ensure the stable amount of taxes collected as a share of the total government revenue, i.e., at the level that had been achieved in the last several years to keep the revenue and expenditure of the BRICS member states' budgets in equilibrium.

The average weighted tax rates in the BRICS can be determined as a percentage ratio of the government budget revenue collected through taxes relative to the gross national income (Table 1).

In 2019, the BRICS, except Russia, had budget deficits. India and South Africa were also running current-account deficits. This is confirmed in many recent papers such as those by Salisu and Akanni (2020) and Zou et al. (2020). In 2020-2021, the expectation by many researchers, such Khan et al. (2020) as well as Tripathi and Kaur (2020), is that the BRICS is going to run bigger budget deficits, current-account deficits, as well as less budget revenue. In the model constructed, the volume of the total government deficit is understood as a total of the current-account and budget deficits of the BRICS. 
Table 1. Tax rates in the BRICS, 2019.

\begin{tabular}{lccccc}
\hline \multicolumn{1}{c}{ Indicator } & Brazil & Russia & India & China & SAR \\
\hline Average weighted tax rate, \% & 22.8 & 18.8 & 6.9 & 19.5 & 28.9 \\
The share of budget expenditure relative to GDP, \% & 49.6 & 36.4 & 11.3 & 31.3 & 40.6 \\
The share of budget revenue relative to GDP, \% & 41.1 & 37.3 & 8.8 & 29.0 & 37.9 \\
Corporate tax, \% & 34.0 & 20.0 & 34.6 & 25.0 & 28.0 \\
Income tax, \% & 27.5 & 13.0 & 34.6 & 45.0 & 41.0 \\
VAT, \% & 17.0 & 20.0 & 15.0 & 17.0 & 14.0 \\
\hline
\end{tabular}

Source: compiled by the author based on International Monetary Fund's Principal Global Indicators.

Since a budget is the document of universal and nationwide significance about revenues and expenditures, achieving its equilibrium is a top priority and the most important objective of a macroeconomic policy in any country (see (Alemany et al. 2020; Hu et al. 2020)). There are three types of budgets, including an equilibrium budget, a deficit budget, and a surplus budget. In the case of the equilibrium budget, government expenditure equals government revenues, and their volumes coincide. In the other two cases, the amounts of government expenses and revenues diverge. If an average weighted tax rate, which signifies budget receipts on the chart, goes above the interest rate of the government debt service, then the budget returns a surplus; otherwise, the budget returns a deficit (Janková and Dostál 2020).

The nationwide average weighted tax rate encompasses the average weights of all tax types, charges, fees, and other tax receivables. To simplify the model, an average rate of debt service is understood as an aggregate relative indicator, which results from the government's obligation to commit all expenditures included in the budget, drawing loans to finance these expenditures from various sources backed by government bonds as well as interest rate debt service (Wu and Zhu 2018; Kim 2019).

To achieve the equilibrium of government budgets and the deficit finance service, according to the conditions of a potential agreement on consensual budgetary and fiscal policies in the BRICS given above, two options could be offered for Brazil, India, China, South Africa, and Russia for any emergency situation that may occur since in the period in question if the governments run enormous deficits (Jain et al. 2020; Sabilla and Kurniasih 2020).

According to option one, a country of the BRICS with a budget deficit, for example India, would have to increase the average weighted tax rate up to a point where the government budget expenditure equals the government budget revenue, while the share of the tax receipts in the total budget revenue remains constant, as in the years prior to the coronavirus crisis. In the case of India, to finance the budget deficit, its government will have to increase the nationwide average tax rate from $6.9 \%$ to $8.8 \%$, thus gaining additional required tax revenue (Figure 1). On the graph of the Indian budget, government expenses and government revenues both appear on the OY-axis, meaning they are dependent variables. GDP is shown on the OX-axis. GDP is the total volume of industrial activity in an economy stimulated by the expenditures that were financed and committed by the government at the expense of budget revenue and loans.

The results of the calculations for the other members of the BRICS say that Brazil would have to increase the average weighted tax rate from $22.8 \%$ up to $27.5 \%$, China from $19.5 \%$ up to $21.1 \%$, and South Africa from $28.9 \%$ up to $31.1 \%$. In contrast, Russia may have well decreased the annual average weighted tax rate from $18.8 \%$ down to $18.4 \%$ because it was running at a budget surplus during the period in question. 


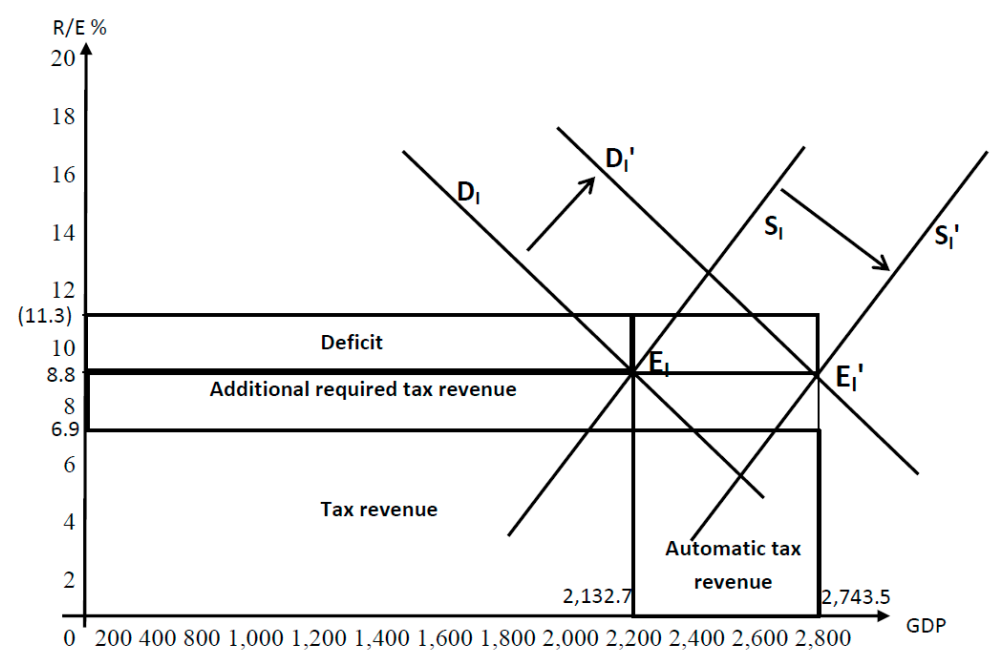

Figure 1. Financing the budget deficit in India.

An alternative option, or option two, which is under consideration in this paper, to achieve the government budget equilibrium and cover the budget deficit, is to create specific economic conditions in the BRICS so that the GDP of the BRICS increases up to a point where economic growth automatically leads to a growing budget revenue received from taxes, keeping the share of tax receipts constant or unchanged relative to total government revenue and also keeping the average weighted tax rate at the previous level for a specific country established prior to the crisis of 2020. For example, Brazil, to make ends meet, should create economic growth in the country, which will lead to a leftward shift in aggregate demand and aggregate supply, hence making automatic tax revenue for the budget (Figure 2).

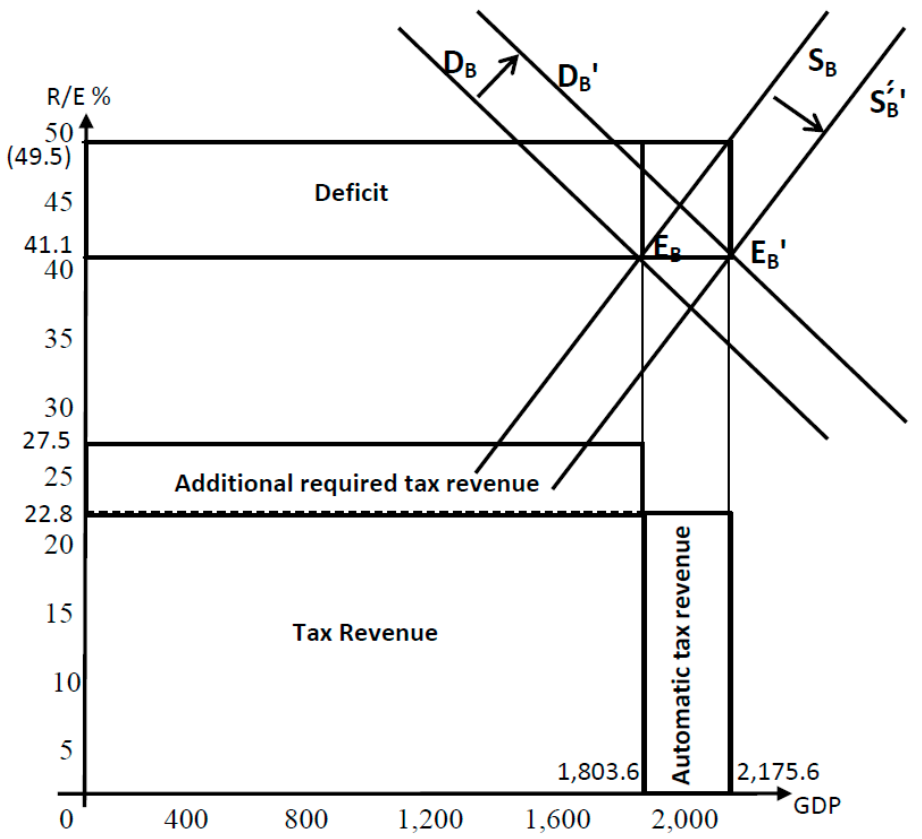

Figure 2. Financing the budget deficit in Brazil.

\section{Results}

According to the model constructed, this alternative option cannot be achieved within one year since it would have required unrealistically high growth rates in the BRICS. For example, to collect the corresponding budget revenue from tax receipts at the previously established average weighted tax rate in Brazil, its economic growth rate should have 
amounted to $17.1 \%$ annually. In India, this would have been $22.3 \%$ and $6.8 \%$ in South Africa. Realistic figures in this particular case could have only been recorded in Russia and China, namely since the Russian budget was running at a surplus at the time, and the equilibrium of government expenditures and revenues would have occurred at a GDP growth rate close to $2 \%$ and even lower (Figure 3 ). To automatically equilibrate government expenditures and revenues, China would have required a $7.3 \%$ growth rate, which practically corresponded to the economic growth patterns in the country at the time, prior to the 2020 crisis (Figure 4).

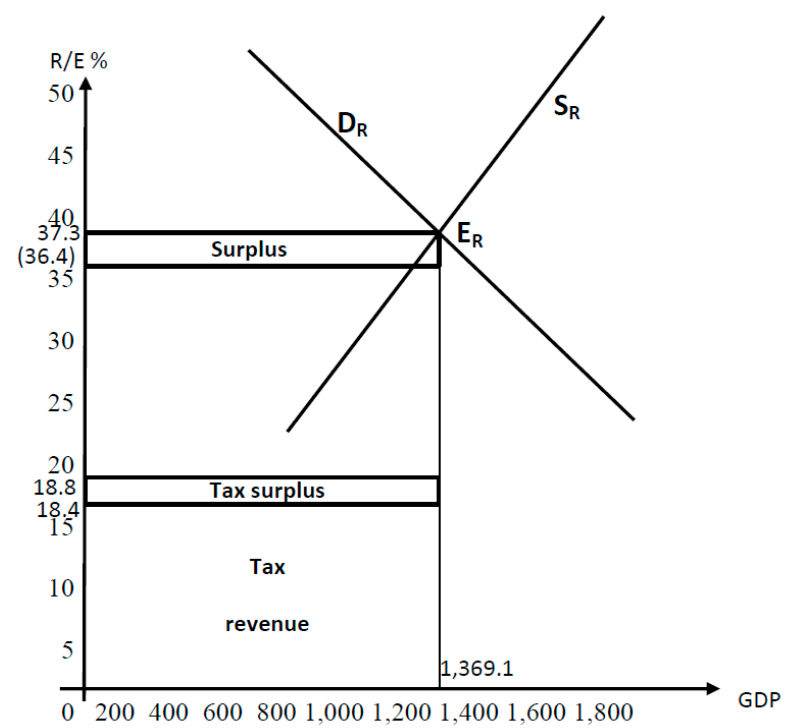

Figure 3. Budget equilibrium in Russia.

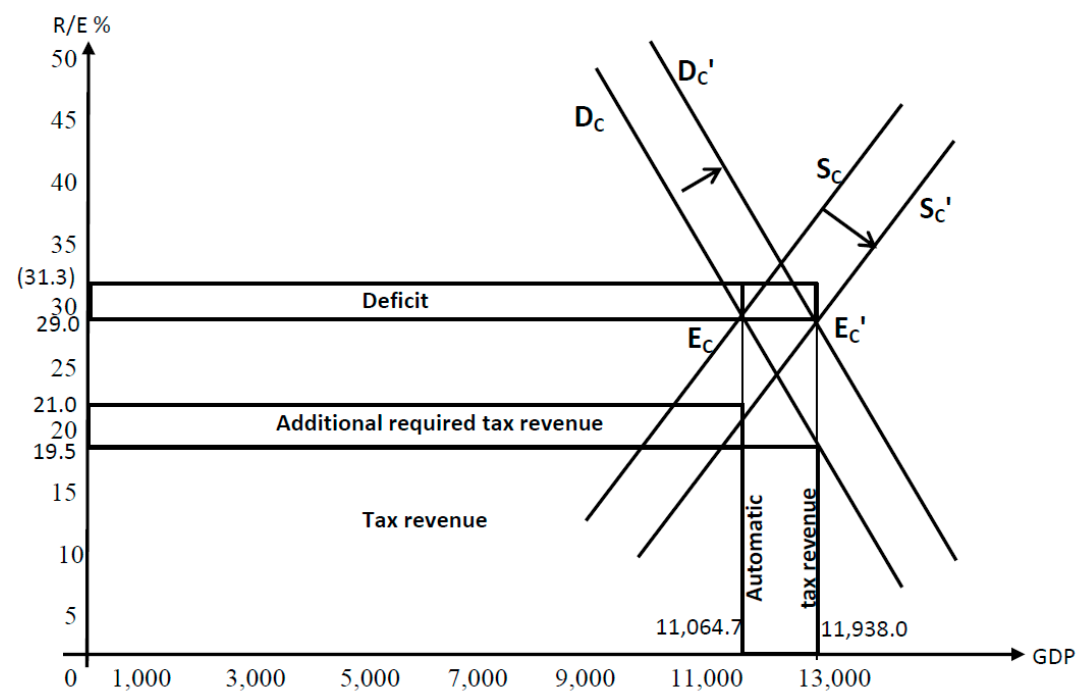

Figure 4. Financing the budget deficit in China.

The automatically achievable equilibrium of expenditures and revenues in the BRICS could have also occurred as a result of GDP growth with their tax rates unchanged. Brazil, India, and South Africa could meet the requirements of this alternative option only if they had followed it for several years by the time their GDP would have achieved the model's projections in the aftermath of the ongoing coronavirus pandemic of 2020. To do this, it would have taken Brazil and South Africa six whole years each, four years for India, and only one year for China (Table 2). 
Table 2. Economic growth rates and the number of years it will take the BRICS to finance government deficits by means of option one and option two.

\begin{tabular}{|c|c|c|c|c|c|}
\hline Indicator & Brazil & Russia & India & China & SAR \\
\hline $\begin{array}{l}\text { Budget revenue received from collected taxes to equilibrate the budget } \\
\text { keeping the share of tax receivables in total government budget revenues } \\
\text { constant, billion dollars }\end{array}$ & 495.4 & 252.2 & 189.4 & 2331.2 & 98.3 \\
\hline $\begin{array}{l}\text { GDP required to equilibrate the budget without increasing the tax rate and } \\
\text { keeping the share of tax receivables in total budget revenues at the } \\
\text { previously established level, billion dollars }\end{array}$ & 2175.6 & 1342.4 & 2743.5 & $11,937.9$ & 339.7 \\
\hline Required GDP growth rate to not increase taxes, $\%$ & 17.1 & -2.0 & 22.3 & 7.3 & 6.8 \\
\hline $\begin{array}{l}\text { A new tax rate required to equilibrate the budget keeping the share of tax } \\
\text { receivables in total budget revenues at the previously established level, \% }\end{array}$ & 27.5 & 18.4 & 8.9 & 21.1 & 31.1 \\
\hline $\begin{array}{l}\text { The number of years required to achieve the new potential GDP taking } \\
\text { into account realistic considerations and prognostic data of the model }\end{array}$ & 6 & 0 & 4 & 1 & 6 \\
\hline
\end{tabular}

Source: composed by the author based on the International Monetary Fund's Principal Global Indicators.

Budget deficits and current-account deficits could be cut by means of the debt instruments traded on the would-be regional debt market of the BRICS. According to the model built, China has the required competitive advantages in providing credit since, compared to Brazil, Russia, India, and South Africa, it has had the lowest annual average weighted government bond rate of $2.4 \%$ at the time of conducting this research. Taking this rate as the rate at which Brazil, Russia, India, and South Africa may have taken loans to cut the government deficit, the volume of the annual debt service in Brazil would have gone down from 20.1 billion to 0.6 billion dollars. In Russia, it would have gone down from 0.5 billion to 0.1 billion dollars; in India, from 13.4 billion to 1.4 billion dollars; and in South Africa, from 13.4 billion to 0.6 billion dollars (Table 3 ).

Table 3. Debt service of the governments by means of the proposed debt instruments on the strength of the BRICS' shared debt market.

\begin{tabular}{|c|c|c|c|c|c|}
\hline Indicator, Billion Dollars (unless Otherwise Specified) & Brazil & Russia & India & China & SAR \\
\hline Exports & 191.1 & 343.9 & 264.4 & 2273.5 & 69.6 \\
\hline Imports & 171.4 & 182.8 & 390.7 & 1679.6 & 79.6 \\
\hline Current-account balance & 19.7 & 161.1 & -126.4 & 593.9 & -10.0 \\
\hline Budget revenue, local currency & 2465.8 & $31,109.9$ & $12,031.3$ & $20,012.8$ & 1528.5 \\
\hline Budget revenue & 741.2 & 510.5 & 187.5 & 3213.6 & 119.8 \\
\hline Budget revenue received from taxes & 410.7 & 257.2 & 147.2 & 2160.6 & 91.6 \\
\hline Budget revenue received from taxes relative to total budget revenue, $\%$ & 55.4 & 50.4 & 78.5 & 67.2 & 76.5 \\
\hline Budget expenditure & 894.0 & 498.4 & 241.3 & 3467.2 & 128.6 \\
\hline Budget balance & -152.8 & 12.1 & -53.7 & -253.6 & -8.8 \\
\hline Government deficit & -152.8 & 0.0 & -180.1 & -253.6 & -18.8 \\
\hline Government debt & 1254.1 & 176.8 & 779.8 & 1807.0 & 152.5 \\
\hline GDP (nominal) & 1803.6 & 1369.1 & 2132.8 & $11,064.7$ & 316.5 \\
\hline Countrywide average weighted tax, $\%$ & 22.8 & 18.8 & 6.9 & 19.5 & 28.9 \\
\hline Expenses-to-GDP ratio, $\%$ & 49.6 & 36.4 & 11.3 & 31.3 & 40.6 \\
\hline Revenue-to-GDP ratio, $\%$ & 41.1 & 37.3 & 8.8 & 29.0 & 37.9 \\
\hline Annual average government bond rates (short term), \% & 13.3 & 9.5 & 6.9 & 2.3 & 7.5 \\
\hline Annual average government bond rates (long term), \% & 13.0 & 9.1 & 7.6 & 3.4 & 9.7 \\
\hline Government debt-to-GDP ratio, \% & 69.9 & 14.0 & 34.5 & 16.1 & 51.8 \\
\hline Budget balance relative to GDP, $\%$ & -8.5 & 0.9 & -2.5 & 0.0 & -2.8 \\
\hline Government loans to finance the government deficit & 152.8 & 5.0 & 180.1 & 253.6 & 18.8 \\
\hline Short-term government bonds & 19.7 & 2.3 & 51.2 & 30.7 & 16.9 \\
\hline Long-term government bonds & 391.0 & 9.3 & 728.6 & 282.2 & 9.3 \\
\hline Local government bonds average weighted rate to finance government deficit, \% & 13.2 & 9.3 & 7.5 & 2.4 & 6.9 \\
\hline Foreign government bonds average weighted rate to finance government deficit, $\%$ & 2.9 & 3.5 & 2.8 & 2.4 & 3.5 \\
\hline Annual debt service at the local loan rate & 20.1 & 0.5 & 13.4 & 6.1 & 1.3 \\
\hline Annual debt service at the foreign loan rate & 0.6 & 0.1 & 1.4 & 0.7 & 0.6 \\
\hline
\end{tabular}


In turn, the local average weighted rate on government bonds in Brazil, Russia, India, and South Africa would have gone down to the respective rates of the Eurobonds (i.e., the author-proposed BRICS-bonds) for each member state of the BRICS, namely: in Brazil, it would have been reduced from $13.2 \%$ down to $2.9 \%$; in Russia, from $9.3 \%$ to $3.5 \%$; in India, from $7.5 \%$ to $2.8 \%$; and in South Africa, from 6.9 to $3.5 \%$. The total volume of the BRICS regional debt market must have been equal for that purpose to the total amount of the required loans to cut the government debt and service interest payments on the BRICS-bonds. According to the model's assumptions, the total regional debt market of the BRICS would have amounted to the face value of the BRICS-bonds, which would have been 610.3 billion dollars plus 3.4 billion dollars as interest on the debt service, totaling in sum 613.7 billion dollars.

The respective figures for the debt service in the BRICS without the regional debt market would be the principal value of government bonds ( 610.3 billion dollars) plus 41.4 billion dollars as interest on the debt service, which in sum would have totaled 651.7 billion dollars.

\section{Discussion}

An important aspect of the model constructed is also the problem of determining the optimal amount of budget deficits and government debt of the BRICS. For example, the Maastricht Treaty of the EU mandated the criteria, which must be met by the member states of the Eurozone that use the euro as the common currency. According to these criteria, the budget deficit must be $3 \%$ of GDP, and the government debt must be $60 \%$ of GDP. However, even taking into consideration the way these criteria are mandated and the appropriate macroeconomic policy instruments to observe them, no country of the Eurozone fully meets them at the time of conducting this research.

Furthermore, at the start of the Eurozone's life, some member states from southern Europe (such as Italy, Greece, and Portugal) did not meet the above criteria at all and were not willing to meet them. Currently, no nation of the Eurozone satisfies the Maastricht criteria.

Projecting these criteria on the BRICS, the member states would have required the introduction of a strict (tight) financial discipline (or a straitjacket), which would have meant specific limits for government expenditure. A tight financial straitjacket in the BRICS would have eventually resulted in braking economic growth, stalling social development and health care, poor education, and few investments in research and development, science and technology, and national defense, etc., i.e., there might have been serious cuts on all positions in the budgets. The potential agreement on the consensual (or shared) fiscal policies in the BRICS would have demanded consequent increases in retirement age due to the aging population.

To receive the respective (relevant) types of budgets for the BRICS, similar graphs can be drawn to specifically represent the BRICS' budgets. Russia's case is a disequilibrium surplus budget. At the time of conducting this research, the surplus of Russia's federal budget amounted to 9.9 billion dollars, with GDP valued at 1.37 trillion dollars. It means that the budget-surplus-to-GDP ratio of Russia was $0.7 \%$.

The case for Brazil, India, China, and South Africa is that of a disequilibrium budget deficit. The Brazilian budget deficit was 152.8 billion dollars, with a GDP of 1803.6 billion dollars in 2019. Therefore, the budget-surplus-to-GDP ratio of Brazil was $8.5 \%$ at the time. This value was three times as large as that prescribed by the Maastricht criteria in the Eurozone example. In turn, the government debt of Brazil was 1254.1 billion dollars, which was about $70 \%$ of its GDP and was also above the level commonly recognized in the Eurozone. If Brazil had turned to domestic loans to cover the budget deficit at that time, its debt would have amounted to $152.8+20.1$ (or 172.9) billion dollars or $9.8 \%$ of GDP in the period in question. If Brazil, on the other hand, had turned to cover its government debt in the same way, the corresponding figures would have been $1254.1+1419.6$ billion dollars or $78.7 \%$ of GDP. If instead, Brazil had turned to use the loans provided at the expense 
of the shared BRICS debt market for the same purpose, the corresponding values would have been $152.8+3.7$ (or 156.5) billion dollars, or 8.7\% of GDP, and 1254.1 + 30.1 (1284.2) billion dollars or $71.2 \%$ of GDP. Similar values calculated for Russia, India, China, and South Africa can be found in Table 3.

In this respect, there arises a question: which level of indebtedness is to be considered optimal for the economy of the BRICS? According to the principles of classical economic theory, the optimal size of an economic entity is generally achieved at the point of equilibrium between total cost and total revenue $(\mathrm{TR}=\mathrm{TC})$.

Hence, the classical level of deficit for an economy is $0 \%$ of GDP. The same goes for the government debt-to-GDP-ratio, which basically means no deficit or debt. However, since government expenditure is always present, it can be likened to the amount of totally covered obligations. The result of all this is if it is understood that in order to pay for all expenses and to equilibrate the budget the government requires loans, then to get an optimal debt-to-GDP ratio for a country, it is necessary to compare the budget expenses with the latter.

At this point, it is necessary to take into consideration that government expenses may grow and bring no positive effect on GDP growth. There subsequently arises the problem of finding the optimal level of expenditure. The budget expenses of Brazil in 2017 amounted to 894 billion dollars, which was $49.5 \%$ of the country's GDP. On the strength of this, it is possible to determine the optimal level of taxation. Thus, the optimal tax rate would be a rate that allows the government to cover all expenses incurred. This method can also be used to find the optimal values for Russia, India, China, and South Africa. Graphically, the method is depicted in Figures 1-4.

The next step of calculations is the estimation of the BRICS government debt share in GDP if loans are in high demand on the shared regional debt market of the BRICS. What should also be taken into consideration when measuring the debt-to-GDP ratio is the amount of additional growth as a result of providing cheaper credit by the BRICS.

The loans received can be consumed by households to buy various durable goods and by companies to invest in the working and physical capital. The effect of this for an economy will be shown by the fact that by making these expenses on consumer durables, households bring additional revenue for producers, and investment in physical and working capital will create nationwide growth of capital and GDP. The impact of investment in physical or working capital for an economy is determined by means of the investment multiplier. The effect of consumption growth should be compared with consumption taxes and corporate income. Once found, these values are optimal for the BRICS. For example, in South Africa, this optimum can be shown on the upper slope of the Laffer Curve. Thus, to get an additional tax revenue of 6.7 billion dollars, the South African government will have to optimize the level of taxation at 31\% (Figure 5). To achieve the optimal level of taxation, South Africa will have to follow one of the two choices on offer to equilibrate the budget deficit, which is depicted in Figure 6.

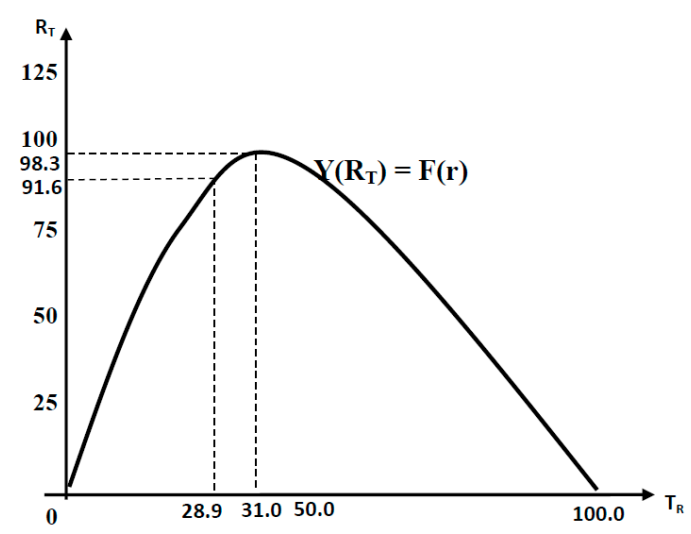

Figure 5. Optimal level of taxation in South Africa. 


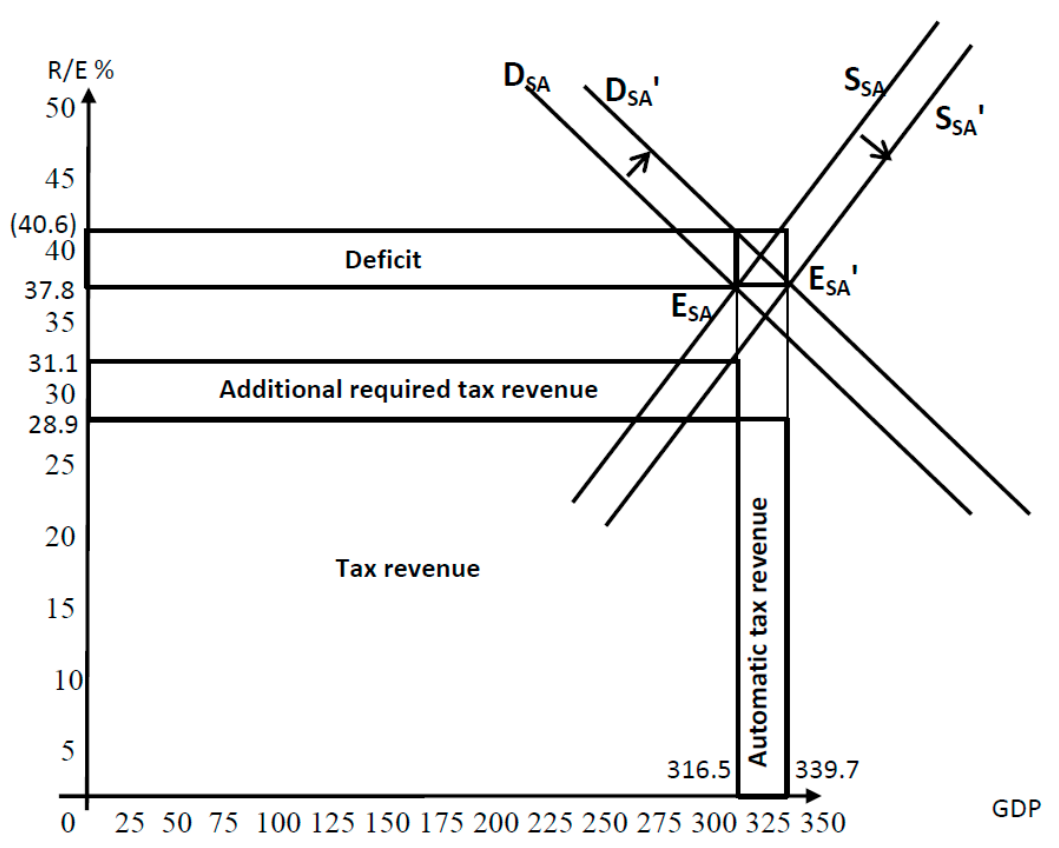

Figure 6. Financing the budget deficit in South Africa.

\section{Conclusions}

This article has presented recommendations for the shared fiscal policy in the BRICS and offers an outlook for the BRICS after the pandemic. The theoretical significance of the paper is that the proposed model of the shared economic mechanism of the BRICS may be a starting point for a new period in globalization based on more cooperation between countries. The practical significance of this research is that its deliverables can be used as policy tools for policymakers to come to an agreement on certain shared economic, political, and social issues.

First of all, the ongoing coronavirus crisis of 2020 made it even clearer than before that the world economy would have been completely ungovernable and chaotic without global cooperation. Therefore, reality demands some decisive policy choices and large-scale plans with every country's participation, including the BRICS. The leaders of the BRICS may find it difficult to come to a common agreement. Reaching a common agreement is a very painful process. The inability to come to common agreements will lead the leaders of the BRICS to continual conflicts. Thus, it is important that the BRICS try to come together on issues such as a shared loan rate on the regional debt market. This will produce more capital needed to overcome the consequences of the pandemic.

Second, the ongoing coronavirus crisis of 2020 has demonstrated that the world is very vulnerable, interconnected, and inclusive in its development. Globalization, the process behind many trends and development paths in the past half-century, has involved the majority of countries. Many of them now share production, investment, communications, etc. Thus, what the BRICS nations can do in return for the prosperity they received from globalization and open-border policies is to come together to discuss and settle the issues of the most urgent importance such as agreeing on a block of shared institutions to govern a shared economic policy. This can be done within any type of grouping or association, be it the UN, G20, or the BRICS. They absolutely must work under the rule of law accepted by the world in 1945 in accordance with the UN Charter so that they do not disrupt the workings of the established system. All organizations, forums, associations, groupings, blocs, development banks, funds, etc., should be complementary and support the foundations of the established world economic and financial order. This is the basis for the prosperity of the BRICS and others, at least in the next couple of decades.

Third, there is a distinct indication showing a certain degree of inclusiveness of many countries, though they might isolate within certain groupings such as the BRICS. This 
inclusiveness and the ability to develop together and side-by-side are perhaps what helped the BRICS gain power in the world economy since the beginning of the 21st century. There is a real economic basis behind this inclusiveness, which, in this case, means that the BRICS may make collective decisions on major issues on the agenda for the world during regular summits to deal with global challenges such as the coronavirus crisis. This leads to the idea that in terms of inclusive development, and contrary to currently wide-spread speculations about deglobalization, the economic model of the BRICS may be considered a new form of integration and economic cooperation in the new world economy and an established, holistic grouping comparable to the model of the newly industrializing nations.

Fourth, although it is impossible to solve the world's problems by dedollarization at the expense of euroization or yuanization, there is some sense to this because it may help diversify global liquidity and mitigate financial risks.

Realistically, China cannot take the responsibility for the entire world to provide the same functions that are now delivered by the US dollar. The world financial community at large will not accept the yuan. If, at the end of the day, China decides to take responsibility for the whole world, it will have to reform its financial system, its banking system, and foreign exchange-rate policy and liberalize capital markets and investment.

If something bad happens in the world, and China will have to print more currency some day in the future, it will be accused, just like the US today, of taking advantage of its supreme currency role in the world monetary system, of having exuberant advantages, of abusing international debt practices, and of accumulating too much foreign debt because, for China, being a world leader will mean the same things and it will face the same challenges as the US today. China will have to provide more aid to the poorest countries, send battleships to control neutral waters, lead peace-making activities across the globe, and negotiate international and regional conflicts, all of which will require huge amounts of money. China will have to provide it somehow, and the only way to do that will be borrowing from the central monetary authority, issuing government bonds, and printing the currency.

Finally, the BRICS has a good chance for more cooperation in helping to reform the world economic order, the world financial architecture, and the world monetary system. The hope is that the BRICS, in the aftermath of the ongoing coronavirus crisis of 2020, will work more closely in digitizing their economic activities. One of the ways to do that will be by establishing a shared debt market.

The hope is that isolation will not take long, and the BRICS will come out of the crisis more economically sustainable and willing to cooperate. In fact, the five countries' ambitions, their willingness to press harder on the Western countries, their ability for sustainable development in conditions of economic sanctions, and, above all, the presence of powerful leaders at the top of the government, may help develop more cooperation in the BRICS since one of the most important characteristics for a group of countries is a strong political will to agree on shared policies.

Funding: This research has been funded by the budget program according to the government assignment given to the Financial University under the Government of the Russian Federation.

Institutional Review Board Statement: Not applicable.

Informed Consent Statement: Not applicable.

Data Availability Statement: Data available in a publicly accessible repository.

Conflicts of Interest: The author declares no conflict of interest.

\section{References}

Alemany, Nuria, Vicent Aragó, and Enrique Salvador. 2020. Lead-lag relationship between spot and futures stock indexes: Intraday data and regime-switching models. International Review of Economics E Finance 68: 269-80. [CrossRef]

Badshah, Waqar, and Mehmet Bulut. 2020. Model selection procedures in bounds test of cointegration: Theoretical comparison and empirical evidence. Economies 8: 49. [CrossRef] 
Cao, Jiasheng, and Jinghan Wang. 2020. Exploration of stock index change prediction model based on the combination of principal component analysis and artificial neural network. Soft Computing 24: 7851-60. [CrossRef]

Dong, Xinyue, Rong Ma, and Honggang Li. 2019. Stock index pegging and extreme markets. International Review of Financial Analysis 64: 13-21. [CrossRef]

Fu, Yizheng, Zhifang Su, Boyu Xu, and Yu Zhou. 2020. Forecasting stock index futures intraday returns: Functional time series model. Journal of Advances in Computer Intelligent Information 24: 265-71. [CrossRef]

Gao, Penglei, Rui Zhang, and Xi Yang. 2020. The application of stock index price prediction with neural network. Mathematical Computer Applications 25: 53. [CrossRef]

Gourinchas, Pierre-Olivier, and Maurice Obstfeld. 2012. Stories of the twentieth century for the twenty-first. American Economic Journal: Macroeconomics 4: 242-49. [CrossRef]

Hou, Yang Greg, and Steven Li. 2020. Volatility and skewness spillover between stock index and stock index futures markets during a crash period: New evidence from China. International Review of Economics E Finance 66: 166-88. [CrossRef]

$\mathrm{Hu}$, Jiang Qian, Tianxiang Wang, Wenwei Hu, and Tong Jun. 2020. The impact of trading restrictions and margin requirements on stock index futures. Journal of Futures Markets 40: 1176-91. [CrossRef]

Jain, Agrawal Tarunika, Sanjay Sehgal, and Rahul Agrawal. 2020. Disruptive innovations, fundamental strength and stock winners: Implications for stock index revisions. Vision-The Journal of Business Perspective 24: 356-70. [CrossRef]

Janková, Zuzana, and Petr Dostál. 2020. Prediction of European stock indexes using neuro-fuzzy technique. Trends Economics and Management 35: 45-57. [CrossRef]

Khan, Karamat, Huawei Zhang, Han Zhang, Huilin Yang, Muhammad Haroon Shah, and Atif Jahanger. 2020. The Impact of COVID-19 Pandemic on Stock Markets: An Empirical Analysis of World Major Stock Indices. Journal of Asian Finance Economics and Business 7: 463-74. [CrossRef]

Kim, Sangbae. 2019. Examination of the nonlinear relationship between stock index and oil prices. Korean Journal of Financial Engineering 18: 107-29. [CrossRef]

Rahman, Mohammed Mizanur, Munni Begum, Badar Nadeem Ashraf, and Md. Abdul Kaium Masud. 2020. Does trade openness affect bank risk-taking behavior? Evidence from BRICS countries. Economies 8: 75. [CrossRef]

Sabilla, Akfika Rizky, and Augustina Kurniasih. 2020. The effect of macroeconomics on stock index. International Journal of Economics and Management Studies 7: 85-92. [CrossRef]

Salisu, Afees A., and Lateef O. Akanni. 2020. Constructing a global fear index for the covid-19 pandemic. Emerging Markets Finance and Trade 56: 2310-31. [CrossRef]

Sun, Peng, Tongfeng Weng, and Huijie Yang. 2019. Evolution of scaling behavior of stock index volatility. Journal of University of Shanghai for Science and Technology 41: 71-76. [CrossRef]

Tripathi, Vanita, and Amanpreet Kaur. 2020. Socially responsible investing: Performance evaluation of BRICS nations. Journal of Advances in Management Research 17: 525-47. [CrossRef]

Tsai, Ming-Chi, Ching-Hsue Cheng, and Meei-Ing Tsai. 2019. A multifactor fuzzy time-series fitting model for forecasting the stock index. Symmetry 11: 1474. [CrossRef]

Wang, Xuebiao, Xi Wang, Bo Li, and Zhiqi Bai. 2019. The nonlinear characteristics of Chinese stock index futures yield volatility: Based on the high frequency data of CSI300 stock index futures. China Finance Review International 10: 175-96. [CrossRef]

$\mathrm{Wu}$, Maoguo, and Zhehao Zhu. 2018. The impact of restrictive measures on the price discovery function of stock index —Evidence from CSI 500 Stock Index Futures. International Journal of Financial Research 9: 117. [CrossRef]

Younsi, Moheddine, and Marwa Bechtini. 2020. Economic growth, financial development, and income inequality in BRICS countries: Does Kuznets' inverted u-shaped curve exist? Journal of the Knowledge Economy 11: 721-42. [CrossRef]

Zou, Peng, Qi Wang, Jinhong Xie, and Chenxi Zhou. 2020. Does doing good lead to doing better in emerging markets? Stock market responses to the SRI index announcements in Brazil, China, and South Africa. Journal of the Academy of Marketing Science 48: 966-86. [CrossRef] 